\title{
Endometriozis’te Tümör Marker ve Nötrofil-Lenfosit Oranının Prediktif Rolü
}

\author{
Tumor Markers and Neutrophil-Lymphocyte Ratio's Predictive Role In \\ Endometriosis
}

Ayhan ATIGAN, Ömer Tolga GÜLER

Pamukkale Üniversitesi Tip Fakültesi Hastaneleri, Kadın Hastalıları ve Doğum ABD, Denizli

Geliş tarihi:19.08.2019 Kabul tarihi: 12.03.2020 DOI: 10.17517/ksutfd.607197

Özet

Amaç:Endometriozis, uterin kavite dişında endometrial dokunun gelişimi ile karakterizedir.Bu çalışmanın amacı, endometriozisli hastaların klinik değerlendirilmesinde nötrofil / lenfosit oranı (NLO) ve bir tümör marker olan kanser antijeni (CA) -125'in prediktif rolünü araştırmaktır.

Gereç ve Yöntemler: Bu retrospektif çalışmada, Ocak 2012 - Aralık 2017 tarihleri arasında Pamukkale Üniversitesi’nde histopatolojik tanısında endometriozisi mevcut olan çeşitli nedenlerle ameliyat edilen toplam 30 hastanın tıbbi verileri analiz edildi.

Bulgular: Endometriozisli hastalarda NLO ve CA-125, kontrol gruba göre istatiksel olarak anlamlı yüksek bulundu.

Sonuç: Cerrahi yapılmadan uygulanabilen bir test olarak NLO ve CA-125, ancak cerrahi sonrası histopatolojik olarak kesin tanısı konulabilen endometriozis hakkında prediktif bilgi verebilir. Tanı için operasyon beklenilmeden medikal tedavi denenebilir. Operasyona hazırlık yapılırken endometriozisi aklımızda bulundurmamıza yardımcı olabilir.

Anahtar kelimeler: Endometriozis, nötrofil/lenfosit oranı, tümör belirteçleri

\begin{abstract}
Objective: Endometriosis is characterized by the development of endometrial tissue outside the uterine cavity. The aim of this study was to investigate the predictive role of neutrophil / lymphocyte ratio (NLR) and cancer antigen (CA) -125, a tumor marker, in the clinical evaluation of patients with endometriosis.

Material and methods: In this retrospective study, the medical data of a total of 30 patients endometriosis in histopathologic diagnosis who underwent surgery due to various reasons between January 2012 to December 2017 at Pamukkale University were analyzed.

Results: NLR and CA-125 were significantly higher in patients with endometriosis than the control group.

Conclusion: NLR and CA-125, which can be applied without surgery, can provide predictive information about endometriosis that can only be diagnosed histopathologically after surgery. Medical treatment can be tried without waiting for the operation. To keep in mind endometriosis when preparing for the operation may help.

Key words: Endometriosis, neutrophil/lymphocyte ratio, tumor markers

Yazışma Adresi: Ayhan ATIGAN Pamukkale Üniversitesi Tıp Fakültesi Hastaneleri, Kadın Hastalıkları ve Doğum ABD, Denizli, Türkiye Tlf: 05447282378 Mail: dratigan@hotmail.com
\end{abstract}

ORCID No(Sırasıyla):0000-0002-7257-0593, 0000-0001-6673-8604 
Endometriosis is defined as the presence of endometrial tissue outside the uterus and is a common disease seen in $5-10 \%$ of women in reproductive age (1). It is an estrogen-dependent chronic inflammatory condition that affects women in their reproductive period, and is associated with pelvic pain and infertility (2). Although dysmenorrhea is the most common symptom, dyspareunia, low back pain, dyschezia, and dysuria are other symptoms (3). Remarkably, the gold standard for the diagnosis of endometriosis remains direct visualization of lesions at surgery preferably coupled with histologic confirmation of endometrial glands and stroma in biopsies of suspected lesions, and this reality has significant consequences. Diagnosis of endometriosis is difficult to confirm due to the wide variety of appearances and symptoms, as well as the unreliable correlation between clinical presentation and surgical findings (4).

Cancer Antigen 125 (CA 125), a well-established marker for epithelial cell ovarian cancer, is derived from coelomic epithelia including the endometrium, fallopian tube, ovary, and peritoneum . CA 125 is raised in endometriosis through stimulation of coelomic epithelia (5). Biological markers such as interleukins and CA-125 have been widely used as well-described markers of endometriosis. However, these tests have not yielded sufficient power to diagnose the initial stages of endometriosis, and they have low sensitivity and specificity compared with laparoscopy (6). Endometriosis may be viewed as a local disease with a systemic, subclinical inflammation process that involves changes in the relative levels of circulating white blood cells (WBCs); neutrophilia is accompanied by relative lymphocytopenia and an increase in serum proteins such as C-reactive protein (CRP) (7). To evaluate whether neutrophil/lymphocyte ratio (NLR) could be diagnostic value in endometriosis, which is a chronic inflammatory disease.

\section{MATERIAL and METHODS:}

\section{Patients}

Data of the study was collected from archive in the Department of Gynecology at Medicine Faculty of Pamukkale University from January 2012 to December 2017. Ethics committee approval was received from our institution. Although more than fifty endometriosis cases confirmed by pathology reports, they were excluded that patients without preoperative tumor marker values. In conclusion, thirty patients were included in the study. All of patients with endometriosis diagnosed by a surgical procedure ( laparoscopy and or laparotomy) and were confirmed by histopathological analysis of surgical material. Indications for operation included chronic pelvic pain, dyspareunia, fibroids, abnormal uterine bleeding, endometrial polyps, adenomyosis, endometriosis, endometrioma and other ovarian cysts.

Inclusion criteria for surgical decision were: absence of endometriosis, absence of pelvic pain in its different forms (dysmenorrhea, dyspareunia or chronic pelvic pain), absence of disease of the uterus, tubes and/or ovaries diagnosed by transvaginal ultrasound or laparoscopy, absence of previous clinical or surgical treatment for endometriosis, absence of other diseases of the uterus, tubes and/or ovaries, a histopathologically confirmed diagnosis of endometriosis.

The control group consisted of patients operated for benign ovarian cyst without no endometriosis history.

\section{Methods}

All patients were submitted to serum determination of CA-125, neutrophil and lymphocyte. The best part of patients were also studied to serum determination of CA 15-3, CA 19-9, carcinoembryonic antigen (CEA), C-reactive protein(CRP) and albumin. The samples were obtained before operation. The NLR was defined as the absolute neutrophil count divided by the absolute lymphocyte count.

\section{Laboratory tests}

Blood was centrifuged and the supernatant was stored until examination. CA-125, CA 15-3, CA 19-9, CEA, c-reactive protein, albumin, neutrophil and lymphocyte were then determined by chemiluminescence. The normal values for these substances are: up to $35 \mathrm{U} / \mathrm{ml}$ for CA-125; up to $25 \mathrm{U} /$ $\mathrm{ml}$ for Ca 15-3; up to $27 \mathrm{U} / \mathrm{ml}$ for CA 19-9; up to $4.7 \mathrm{ng} / \mathrm{ml}$ for CEA; up to $0.5 \mathrm{mg} / \mathrm{dL}$ for CRP; from 3.5 to $5.2 \mathrm{~g} / \mathrm{dL}$ for albumin; from 1.9 to $8.0 \mathrm{~K} / \mathrm{uL}$ for neutrophil ; from 0.9 to 5.2 $\mathrm{K} / \mathrm{uL}$ for lymphocyte.

\section{Statistical analysis}

The data were evaluated by IBM SPSS version 21 (IBM statistics for Windows version 17, IBM Corporation, Armonk, New York, USA) statistic software. The data were expressed as mean \pm standard deviation. We used The Independent-Samples $\mathrm{T}$ Test. The Independent-Samples $\mathrm{T}$ Test procedure compares means for two groups of cases. The level statistical significance was set at $\mathrm{p}<0.05$.

\section{RESULTS}

When the patients were evaluated in terms of age, albumin levels, lymphocyte levels, there was no difference between the groups (all $\mathrm{p}>0.05$ ). Demographic, biochemical and hematological parameters of the groups are shown in Table 1, all of participants (endometriosis group) were thirty patients. Hysterectomy with unilateral salpingo-oophorectomy (USO) was performed laparoscopic one of them and in same group other four were done by abdominally. Total abdominal hysterectomy with bilateral salpingo-oophorectomy (BSO) group were 25 patients. 


\begin{tabular}{|c|c|c|c|c|c|}
\hline Variables & Group & $\mathbf{N}$ & Mean & Std. Deviation & Min-Max \\
\hline \multirow[t]{2}{*}{ Age (years) } & Endometriosis & 30 & 42.9 & 3.9 & $33-48$ \\
\hline & Control & 30 & 40.9 & 6.9 & $19-48$ \\
\hline \multirow[t]{2}{*}{ CA $125(\mathrm{U} / \mathrm{ml})$} & Endometriosis & 30 & 105.00 & 105.1 & $9.1-449.5$ \\
\hline & Control & 30 & 25.77 & 27.9 & $7.2-107.9$ \\
\hline \multirow[t]{2}{*}{ CA 15-3 (U/ml) } & Endometriosis & 27 & 19.08 & 10.9 & $5.4-48.8$ \\
\hline & Control & 30 & 14.74 & 6.2 & $4.3-28.3$ \\
\hline \multirow[t]{2}{*}{ CA 19-9 (U/ml) } & Endometriosis & 27 & 29.16 & 39.1 & $0.6-150.1$ \\
\hline & Control & 29 & 15.86 & 18.6 & $0.6-101.8$ \\
\hline \multirow[t]{2}{*}{ CEA (ng/ml) } & Endometriosis & 26 & 1.49 & 1.4 & $0.3-7.8$ \\
\hline & Control & 28 & 1.45 & 0.7 & $0.3-3.8$ \\
\hline \multirow[t]{2}{*}{$\mathrm{CRP}(\mathrm{mg} / \mathrm{dL})$} & Endometriosis & 15 & 2.93 & 5.4 & $0.1-19.3$ \\
\hline & Control & 17 & 0.27 & 0.2 & $0.1-0.8$ \\
\hline \multirow[t]{2}{*}{ Albumin (g/dL) } & Endometriosis & 15 & 4.13 & 0.4 & $3-4.6$ \\
\hline & Control & 17 & 4.43 & 0.3 & $3.8-5.1$ \\
\hline \multirow[t]{2}{*}{ Neutrophil (K/uL) } & Endometriosis & 30 & 5.29 & 2.5 & $2.6-16.4$ \\
\hline & Control & 30 & 4.09 & 1.2 & $1.9-6.7$ \\
\hline \multirow[t]{2}{*}{ Lymphocyte (K/uL) } & Endometriosis & 30 & 2.02 & 0.5 & $0.8-3.0$ \\
\hline & Control & 30 & 2.12 & 0.6 & $1.2-3.5$ \\
\hline
\end{tabular}

Table 2. Demographic and laboratory data of patients

\begin{tabular}{|l|c|c|c|}
\hline Variables & Control & Endometriosis & p value \\
\hline Age $($ years $)$ & 40,9 & 42,9 & 0.183 \\
\hline CA $125, \mathrm{U} / \mathrm{ml}$ & 25,77 & 105,00 & $<0.001$ \\
\hline CA $15-3, \mathrm{U} / \mathrm{ml}$ & 14,74 & 19,08 & 0.068 \\
\hline CA $19-9, \mathrm{U} / \mathrm{ml}$ & 15,86 & 29,16 & 0.107 \\
\hline CEA, ng/ml & 1,45 & 1,49 & 0.893 \\
\hline CRP/Albumin & 0,06 & 0,80 & 0.057 \\
\hline Neutrophil/lymphocyte & 2,12 & 2,74 & 0.021 \\
\hline
\end{tabular}

As shown in the Table 2, CA $125(\mathrm{p}<0.001)$ and NLR (0.021) was found statistically significant in endometriosis group to compared control group. CA 125 and NLR were increased in the patients with endometriosis.

\section{DISCUSSION}

Endometriosis, one of the most commonly encountered gynecologic diseases, affects approximately 5 to $10 \%$ of women of childbearing age $(1,8)$. Endometriosis is responsible for chronic pelvic pain and unexplained infertility (2).Transvaginal and transrectal ultrasound, pelvic magnetic resonance imaging (MRI), colonoscopy, and cystoscopy may help in the diagnosis of endometriosis. In endometriosis extremely increased tumor markers are determined in the case of ruptured endometrioma cyst. There are two mechanisms to clarify extremely elevated levels of CA 125 in endometriosis. First, the peritoneal irritation of CA-125 molecule after the rupture of endometioma cyst and CA-125 secretion from the periton. And the second is penetration of the CA-125 molecule easily to the circulation through the peritoneal endothelial surface after the cyst rupture.

The preferred method for diagnosis of endometriosis is surgical visual inspection of pelvic organs with histologic confirmation (3). However, Yang et al. found that the diagnostic value of NLR combined with CA-125 increased in patients with endometriosis (9).

Tazegul et al. reported that mean age was $50 \pm 5.2$ for hys-

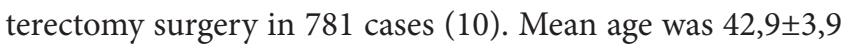
and so lower in our study. Hysterectomy and bilateral salpingo-oophorectomy definitively treat pain from endometriosis at 10 years in 90 percent of patients (3). 
A diagnostic test without the need for surgery will reduce the associated surgical risks, increase accessibility to a diagnostic test and improve treatment outcomes (11). Endometriosis goes along to be a disease of difficult approach both in diagnostic and therapeutic terms. However, the results of our study suggest that NLR was contributed to the diagnostic value of CA-125 in the preoperative differential diagnosis of endometriosis. In a 2008 study, Cho et al. recommended the use of NLR as a diagnostic marker in patients with endometriosis, reporting an NLR sensitivity and specificity of around 60 percent; however, NLR combined with CA-125 increased sensitivity, but decreased specificity (12). The NLR is elevated in patients with endometriosis, and it demonstrated high sensitivity in detecting endometriosis when used in combination with CA-125 (12). Some studies show that CA 19-9 may be demonstrably elevated in endometriosis and exhibit the same or decreased sensitivity as CA-125 (13). However, elevated values for CA 19-9 with endometriosis were no statistically significant in our study. Several studies have demonstrated the utility of CA-125 for the diagnosis of endometriosis and its correlation to disease severity, especially endometriotic ovarian cysts. However, CA-125 is not specific for endometriosis, being a tumor marker elevated in ovarian cancer. In addition to this lack of specificity, the sensitivity to detect all endometriosis stages is low (13).

Endometriosis is an inflammatory process associated with altered function of immune-related cells in the peritoneum and may be viewed as a local disease with systemic, subclinical inflammation. C-reactive protein, an indirect marker of inflammatory processes, has been found to be increased in the patients with endometriosis (12). We also found higher values of CRP in endometriosis group.

Endometriosis is histologically characterized by the displacement of endometrial tissue to extrauterine locations including the pelvic peritoneum, ovaries, and bowel. An important cause of infertility and pelvic pain, the individual and global socioeconomic burden of endometriosis is significant. Laparoscopy remains the gold standard for the diagnosis of the condition (13). However, the invasive nature of surgery, coupled with the lack of a laboratory biomarker for the disease, results in a mean latency of 7-11 years from onset of symptoms to definitive diagnosis (13). Unfortunately, the delay in diagnosis may have significant consequences in terms of disease progression. The discovery of a sufficiently sensitive and specific biomarker for the nonsurgical detection of endometriosis promises earlier diagnosis and prevention of deleterious sequelae and represents a clear research priority.

The weakness of the study is its retrospective design and our findings should be confirmed with prospective studies. There are some other limitations to our study. First, because changes in differential WBC counts and NLR are involved in the inflammatory process, all other acute inflammatory processes must be excluded before using them as a diagnostic tool for endometriosis. Second, the timing of blood collection for CA-125 in relation to the menstrual cycle is known to affect significantly this test (12). Although mean serum levels of CA-125 were increased in the proliferative phase, whereas KSU Medical Journal 2020;15(2) : 20-23
NLR had no significant phase specific differences, the menstrual dates used in this study were obtained only by review of medical records; histologic confirmations were not made. We could not staging for endometriosis due to its retrospective nature. Confirmation in larger cohorts of patients should be obtained and, if confirmed, this simple measurement from the complete blood counts, in conjunction with serum CA125 , may lead to a more accurate diagnosis of endometriosis.

Our study has some limitations including the stages of endometriosis cannot be reached due to retrospective nature of the study. Especially, for crp/albumin ratio should study much more patients group due to its differences with literature.

In conclusion, we recommend further studies investigating the relationship between NLR, CRP/Albumin ratio and CA-125 and pelvic inflammatory disease symptoms, adhesions and stage of endometriosis.

Conflict of Interest and Financial Status: Our study has not been financed by an institution and institution. In this study, there is no conflict of interest among the authors on any subject.

\section{REFERENCES}

1. Giudice LC, Kao LC. Endometriosis. Lancet 2004;364:1789-99.

2. Giudice LC, Clinical practice Endometriosis. N. Engl. J. Med. 2010;362:2389-98.

3. Mounsey AL, Wilgus A, Slawson DC. Diagnosis and management of endometriosis. American Family Physician. 2006;74:594-600.

4. Wellbery C. Diagnosis and treatment of endometriosis. American Family Physician. 1999; 60:1753-62.

5. Barbieri RL, Niloff JM, Bast Jr. RC, Scaetzl E, Kistner RW, Knapp RC. Elevated serum concentrations of CA-125 in patients with advanced endometriosis. Fertil Steril 1986;45:630-4.

6. May KE, Conduit-Hulbert SA, Villar J, Kirtley S, Kennedy SH, Becker CM. Peripheral biomarkers of endometriosis: a systematic review. Hum Reprod Update 2010;16: 651-74.

7. Kajihara H, Yamada Y, Kanayama S, Furukawa N, Noguchi T, Haruta $S$ et al. New insights into the pathophysiology of endometriosis: from chronic inflammation to danger signal. Gynecol Endocrinol 2011;27:73-9.

8. Viganò P, Parazzini F, Somigliana E, Vercellini P. Endometriosis: epidemiology and aetiological factors. Best Pract Res Clin Obstet Gynaecol. 2004;18:177-200.

9. Yang H, Lang JH, Zhu L, Wang S, Sha GH, Zhang Y. Diagnostic value of the neutrophil-to-lymphocyte ratio and the combination of serum CA-125 for stages III and IV endometriosis. Chin Med J 2013;126:2011-14.

10. Tazegül A, Acar A. Klinigimizde Gerceklestirilen Histerektomi Olgularının Klinik ve Demografik Ozelliklerinin Degerlendirilmesi. Selçuk Tip Derg 2010;26:19-22.

11. Nisenblat V, Bossuyt PM, Shaikh R, Farquhar C, Jordan $\mathrm{V}$, Scheffers CS, et al. Blood biomarkers for the noninvasive diagnosis of endometriosis. Cochrane Database Syst Rev 2016;1;2016(5):CD012179..

12. Cho S, Cho H, Nam A, Kim HY, Choi YS, Park KH, et al. Neutrophil-to-lymphocyte ratio as an adjunct to CA-125 for the diagnosis of endometriosis. Fertil Steril 2008;90:2073-9.

13. Fassbender A, Burney RO, O DF, D’Hooghe T, Giudice L. Update on biomarkers for the detection of endometriosis. Biomed Res Int 2015;13:08-54. 